\title{
Analisis Korelasi Antara Ketertiban Belajar Dengan Hasil Belajar
}

\author{
Muspawi, Emosda, Diana \\ Universitas Jambi
}

Email: muspawi01@gmail.com,

Email: Emosda.Unja@gmail.com

Email: Diana-14@gmail.com

\begin{abstract}
ABSTRAK
Penelitian ini bermaksuduntuk menganalisis serangkaian data agar diketahui: (1) Gambaran kualitas ketertiban belajar siswa didalam kelas pada mata pelajaran PKn (2) Kualitas hasil belajar (3) hubungan keteraturan atau ketertiban belajar siswa didalam kelas dengan hasil belajar. Metode yang dipakai di dalam proses penelitian ini adalah metode kuantitatif dengan jenis korelatif. Penelitian ini dilaksanakan di SD Negeri No. 20/1 Jembatan Mas pada kelas tinggi semester ganjil. Jumlah populasinya adalah 120 orang siswa ditetapkan dengan mengambil 50\% jumlah semua siswa. Teknik pengambilan sampel menggunakan teknik probality sampling, dan jumlah sampelnya 60 siswa. Instrument pengumpulan data memakai angket dengan pola skala likert. Hasil penelitian ini menunjukan bahwa ketertiban belajar siswa didalam kelas dengan hasil belajar PKN kelas tinggi adalah termasuk kategori baik dengan nilai rata-rata 0,498 , untuk hasil belajar siswa kelas tinggi adalah termasuk kategori tinggi dengan nilai rata-rata 70,07 sampai 77,33. Berdasarkan perhitungan product moment diperoleh $r_{\text {hitung }}>r_{\text {tabel }},(0,498>0,254)$, dapat diinterprestasikan bahwa antara ketertiban belajar siswa didalam kelas dengan hasil belajar PKn kelas tinggi SD Negeri No. 20/1 Jembatan Masterdapat hubungan yang signifikan. Kesimpulan ialah terdapat hubungan ketertiban belajar siswa didalam kelas dengan hasil belajar PKN kelas tinggi.
\end{abstract}

Keywords: Ketertiban Belajar Siswa, Hasil Belajar.

\section{PENDAHULUAN}

Sarana penting untuk pembentukan dan penciptaan sumber daya manusia yang berkualitas adalah pendidikan, baik melalui pendidikan dirumah maupun melalui pendidikan disekolah. Tanpa adanya pendidikan dirumah maupun disekolah akan susah untuk melahirkan sumber daya manusia yang baik dan berkualitas dan dapat menentukan masa depan bangsa sendiri. Sekolah sebagai lembaga pendidikan dituntut untuk selalu meningkatkan kualitas atau mutu lembaga pendidikan atau sekolah itu sendiri dengan konsep, rancangan, atau kerangka pendidikan nasional.

Pendidikan nasional memiliki tujuan yang mulia, sebagaimana ditetapkan dalam Undang-Undang Nomor 20 tahun 2003 tentang sistem pendidikan nasional adalah untuk mencerdaskan kehidupan bangsa dan mengembangkan manusia Indonesia seutuhnya, yaitu manusia Indonesia yang memiliki keimanan dan ketakwaan yang kuat kepada Tuhan Yang Maha Esa, berbudi pekerti luhur, berkepribadian mandiri, berpikiran maju, berjiwa tangguh, cerdas, kreatif, terampil tertib, dan bekerja keras, profesional, dan bertanggung jawab, serta sehat jasmani dan rohani. Inti dan hal terpenting dari suatu kegiatan pendidikan berupa proses belajar mengajar, sebagai inti dari kegiatan pendidikan maka proses belajar dapat diposisikan sebagai suatu usaha untuk menggapai tujuan pendidikan. Sedangkan tujuan dari Pendidikan itu sendiri merupakan usaha untuk memberikan perumusan hasil yang diharapkan siswa sebagai subjek belajar, setelah mereka melaksanakan atau menyelesaikan proses belajar atau mendapatkan pengalaman belajar. Oleh karenanya, Muspawi (2017) mengatakan bahwa pendidikan merupakan hal yang sangat penting bagi kehidupan manusia, karena melalui pendidikan akan menghantarkan manusia pada tangga kesuksesan dan menjadi manusia yang seutuhnya. 
Belajar menurut Sutikno (2013:3) merupakan sebuah proses dan usaha yang dilaksanakan seseorang untuk memperoleh perubahan terbaru, yang merupakan bukti ketercapaiandari apa dialaminya sendiri dalam berinteraksi dan melakukan penyesuaian terhadap lingkungan kehidupannya. Dengan kata lain belajar adalah suatu aktivitas yang dilaksanakan dalam keadaan sadar dengan pola tertentu dalam rangka mencapai tujuan yang telah ditargetkan.

Berlandaskan perihal tersebut dapat dimengerti bahwa belajar mengajar adalah serangkaian aktivitas pembelajaran yang konsisten, teguh dan berkesinambungan menuju kearah tujuan yang telah ditetapkan. Yang terpenting dalam proses belajar mengajar adalah anak didik diposisikan sebagai subjek dari suatu kegiatan pengajaran, selain itu peran guru tidak kalah pentingnya, oleh karena itu proses pengajaran tidak lain adalah berupa aktivitas belajar anak didik dalam mencapai tujuanbelajar yang telah ditetapkan, yang terwujud dalam bentuk suatu hasil belajar.

Indikator keberhasilan baik bagi seorang guru maupun siswa adalah hasil belajar, oleh karenanya hasil belajar merupakan hal yangsangat penting sekali.Hasil belajar siswa bagi seorang guru dapat dijadikan sebagai pedoman atau acuan penilaian terhadap kesuksesan dalam kegiatan pembelajaran. Sedangkan bagi siswa, hasil belajar atau nilai raport merupakan pedoman dan informasi yang berfungsi sebagai alat ukur untuk mengetahui tingkat kemampuan dan keberhasilan belajarnya. Setiap individu yang menjalankan suatu proses pendidikan pastinya menginginkan hasil yang optimal. Untuk mencapainya harus ada interaksi yang tertib dalam proses belajar mengajar. Ketertiban disini diartikan sebagai suatu pola proses pembelajaran siswa diadalam kelas dengan ketentuan yang sudah ada didalam kelas dan dipatuhi oleh seluruh pihak secara sadar dan suka rela, baik oleh pihak guru maupun para peserta didik/ siswa.

Dengan demikian ia akan senantiasa belajar dengan sungguh-sungguh untuk kemajuan dan kepentingan dirinya. Jika ketertiban belajar siswa ini dikembangkan ke arah yang positif maka peluang untuk memperolehkeberhasilandalam penyelesaian tugas-tugas yang diberikan oleh gurunya akan sangat besar. Di sini siswa harus mempunyai harapan-harapan dan inspirasi yang cukup tinggi, agar semua tugas dapat dituntaskan dengan baik dan benar.

Hasil belajar siswa akan optimal apabila siswa tersebut mau berusaha keras dan dengan ketertiban yang tinggi juga disertai dengan kepatuhan terhadap aturan dan norma. Ketertiban siswa dalam belajar juga menjadi salah satu penentu keberhasilan diberbagai aspek kehidupan. Demikian juga dengan aspek pendidikan, yang untuk mencapai sebuah keberhasilan harus ada suatu ketertiban. Jika ketertiban tidak diterapkan dalam suatu usaha, pada akhirnya dapat membawa dampak yang tidak baik terhadap hasil usaha. Salah satu bentuk ketertiban yang harus dimiliki siswa ialah ketertiban belajar siswa dalam perihal penentuan dan penggunaan cara belajar, memanfaatkan waktu ketika belajar, dan menyelesaikan berbagai tugas yang disampaikan oleh guru baik tugas dirumah ataupun tugas dikerjakan sewaktu berada di sekolah.

Ketertiban belajar siswa bukan hanya bergantung pada suatu aspek, banyak faktor yang mempengaruhi bangkit tidaknya ketertiban dalam diri siswa. Diantaranya faktor guru, orang tua, masyarakat di lingkungannya, teman-teman, bahkan dirinya sendiri. Ketertiban belajar siswa didalam kelas mempunyai peran yang penting di dalam meningkatkan hasil belajar siswa. Untuk menjadi seorang siswa yang mampu melaksanakan tugas-tugas yang diberikan guru dan tanggung jawab tersebut dengan baik, maka siswa yang kreatif dituntut untuk senantiasa meningkatkan kemampuan ketertiban diri. Tanpa adanya kesadaran akan sebuah ketertiban dari dalam diri siswa (ketertiban dalam materi) maka sulit sekali untuk mencapai hasil maksimal dari suatu pembelajaran.

Menurut Suryosubroto (2010:82) tata tertib yang harus dipatuhi oleh siswa sebagai berikut: 1). Kehadiran siswa di dalam kelas, meliputi: a) Siswa hendaknya hadir setiap hari 
efektif belajar, dan telah memasukiruangan kelas sebelum dimulainya kegiatan pembelajaran. b) Sebelum pelajaran dimulai,siswa hendaknya sudah benar-benar siap menerima pelajaran sesuai dengan jadwal yang telah ditetapkan. c) Jika siswa meninggalkan kelas sebelum waktunya,iahendaknya mendapat izin terlebih dahulu dari guru mata pelajaran. d) Siswa harus sudah siap menerima pelajaran dengan jadwal sebelum pelajaran dimulai. e) Saat jam istirahat tiba, para siswa tidak dibenarkan tinggal atau berada didalam kelas tanpa terkecuali, kecuali jika keadaan tidak memungkinkan, misalnya hujan. f) Jika jam pelajaran telah selesai, siswa boleh pulang. g) Seluruh siswa wajib menjaga kebersihan dan keindahan sekolah. 2). Kerapian siswa dalam berpakaian, meliputi: a) Memiliki logo resmi sekolah yang dijahit pada bagian lengan baju sebelah kiri. b) Rapi, bersih, pantas, tidak terlalu ketat, harus memakai kaos dalam/singlet. c) Memakai baju sesuai dengan aturan sekolah. 3) Penampilan fisik atau diri siswa, meliputi: a) Rambut seluruh siswa tidak menutupi telinga, kerah baju, alis mata, dan tidak terlalu panjang (Laki-laki). b) Rambut siswa tidak boleh berantakan, rambut harus rapi bagi perempuan, jika panjang harus di ikat, dan tidak boleh mengenakan barang yang berlebihan bagi siswa SD.

Penelitian ini dilakukan di SD Negeri No. 20/I Jembatan Mas pada siswa kelas tinggi. alasan penulis memilih kelas tinggi karena sangat memungkinkan untuk dijadikan subjek penelitian. Penulis memilih SD Negeri No. 20/I Jembatan Mas sebagai tempat penelitian karena dari informasi yang diperoleh pada saat observasi bahwa di SD tersebut belum pernah dilakukan penelitian mengenai hubungan keteraturan atau ketertiban belajar para peserta didik didalam kelas dengan hasil belajar mereka (siswa).

Keberhasilan pembelajaran dipengaruhi oleh ketertiban belajar siswa di dalam kelas dan hasil belajar siswa. Siswa yang mempunyai ketertiban belajar di dalam kelas dalam proses aktivitas belajar mengajar dimungkinkan mempunyai hasil belajar yang baik karena siswa lebih mudah dan nyaman mengikuti pembelajaran, sedangkan siswa yang tidak mempunyai ketertiban belajar didalam kelas berada pada kemungkinan memiliki hasil belajar yang rendah cenderung lebih susah untuk mengikuti rangkaian proses pembelajaran.

Fenomena yang terjadi atau kenyataan yang ada pada SD Negeri No. 20/1 Jembatan Mas, siswa yang memperoleh nilai hasil belajar diatas standar hanya sekitar 50\%, sedangkan $50 \%$ siswa yang lainnyanilai hasil belajar yang diperolehnya dibawah standar KKM (65). Selain dari hasil belajar tersebut ketertiban belajar siswa didalam kelas juga kurang, dilihat dari ketertiban belajar siswa yaitu ketertiban siswa dalam menentukan cara belajar dan cara siswa memanfaatkan waktu dalam belajar serta ketertiban dalam melakukan berbagai tugas yang disampaikan oleh guru. Dari sekian banyak siswahanya $60 \%$ dari jumlah siswa yang melaksanakan tugas-tugas di dalam belajar, sedangkan $40 \%$ lainya tidak melaksanakan tugastugas yang diberikan oleh gurunya.Berlandaskan hal tersebut, maka penulis menganggap penting adanya kajian ilmiah untuk diketahui tentang terdapat atau tidaknya korelasi keteraturan atau ketertiban belajar siswa di dalam kelas dengan hasil belajar mereka.

Pokok masalah dalam penelitian ini ialah: 1). Bagaimanakah gambaran kualitas ketertiban belajar siswa didalam kelas pada mata pelajaran Pendidikan Kewarganegaraan (PKn)kelas tinggi Sekolah Dasar Negeri No. 20/1 Jembatan Mas?. 2). Bagaimanakah kualitas hasil belajar pada 1 pelajaran PKnkelas tinggi Sekolah Dasar Negeri No. 20/1 Jembatan Mas? 3). Apakah terdapat hubungan ketertiban belajar siswa didalam kelas dengan hasil belajar pada 1 mata pelajaran PKn kelas tinggi Sekolah Dasar Negeri No. 20/1 Jembatan Mas?.

\section{METODE PENELITIAN}

\subsection{Jenis Penelitian}

Jenis penelitian ini adalah penelitian korelatif, yang mana peneliti mencari hubungan antara ketertiban belajar siswa di dalam kelas dengan hasil belajar siswa kelas tinggi SD Negeri No. 
20/1 Jembatan Mas. Berdasarkan keterhubungan antara variabel X (ketertiban belajar siswa di dalam kelas) dan variabel Y (hasil belajar). Data penelitian ini dalam bentuk angket untuk variabel X (ketertiban belajar siswa di dalam kelas) dan nilai untuk variabel Y (hasil belajar), kuantitatif meruapakan pendekatan yang digunakan di dalam penelitian ini. Langkah-langkah yang di tempuh dalam penelitian ini dipakai untuk meneliti pada populasi atau sampel tertentu, proses pengumpulan data memakai instrument penelitian, analisis data dalam penelitian ini bersifat kuantitatif yangbertujuan membuat gambaran tentang suatu gambaran atau keadaan secara objektif.

\subsection{Populasi dan Sampel.}

\subsubsection{Populasi.}

Populasi menurut Sugiyono (2010:117) adalah wilayah generalisasi yang terdiri atas obyek/subyek yang memiliki kualitas dan karakteristik tertentu yang mana peneliti menetapkannya untuk dipahami, dipelajari dan kemudian dilakukan penarikan kesimpulan. Populasi yang ditetapkan dalam penelitian ini adalah para siswa kelas tinggi Sekolah Dasar Negeri No.20/1 Jembatan Mas. Jumlah siswa kelas tinggi adalah 120 orang siswa yang terdiri dari kelas 4 A sebanyak 19 orang, kelas 4 Bsebanyak 21 orang, kelas 5 A sebanyak 23 orang, kelas 5 B sebanyak 24 orang, kelas 6 A sebanyak18 orang, dan kelas 6 B sebanyak 15 orang.

\subsubsection{Sampel.}

Sampel menurut sugiyono (2010:118) ialah bagian dari jumlah dan karakteristik yang dipunyai oleh suatu populasi. Peneliti dapat memakai sampel yang ditarik dari populasi tersebut, bila populasi besar, dan penelitian tidak mungkin mempelajari semua yang ada pada populasi, seperti karena keterbatasan dana, tenaga dan waktu,

Jika subjeknya kurang dari 100, maka menurut Arikunto (2006:134)sebaiknya semuanya diambil, sehingga penelitiannya dapat dikatakan sebagai penelitian populasi, tetapi jika subjeknya berjumlah lebih dari 100 atau jumlah subjeknya besar, maka sampel dapat ditarik antara $10-15 \%$ atau $20-25 \%$ atau lebih. Berlandaskan uraian tersebut maka sampel penelitian ini ditetapkan sebesar 50\% dari jumlah keseluruhan siswa kelas tinggi di Sekolah Dasar Negeri No. 20/1 Jembatan Mas.

Populasi yang dipakai dalam penelitian ini terdiri atas beberapa kelas, maka dalam hal ini peneliti memakai teknik probality sampling. Menurut sugiyono (2010: 120) probality samplingialah teknik pengambilan sampel yang memberikan peluang yang sama bagi setiapanggota (unsur) populasi untuk dipilih sebagai anggota sampel". Pengambilan sampel di dalam penelitian dilakukan secara acak atau random, yang mana seluruh anggota populasi memperolehpeluang yang sama untuk dijadikan sebagai sampel. Jumlah populasi dalam penelitian ini adalah 120 orang. Maka dapat diketahui bahwa jumlah sampelnya ialah: $120 \mathrm{X}$ $50 \%=60$ siswa.

\subsection{Instrumen Penelitian}

Adapun instrumen yang digunakan dalam penelitian ini adalah sebagai berikut:

\subsubsection{Angket.}

Angket menurut Sugiyono (2006:199) ialah teknik pengumpulan data yang dilaksanakan dengan cara memberikan seperangkat atau pernyataan tertulis kepada para responden agar mereka memberikan jawabannya. Angket bisa berupa pertanyaan atau pernyataan terbuka atau tertutup. Angket dikembangkan oleh peneliti berdasarkan kisi-kisi instrument ketertiban belajar siswa di dalam kelas. Selanjutnya angket yang telah dikembangkan di dalam penelitian ini disebarkan kepada para responden untuk diisi 


\subsubsection{Dokumentasi.}

Dokumentasi menurut Arikunto (2002:135) merupakan suatu kata yang berasal dari kata dokumen yang bermakna barang-barang terulis. Dokumentasi yang diperlukan dalam penelitian ini adalah dokumentasi hasil belajar siswa kelas tinggi SD Negeri No. 20/1 Jembatan Mas berupa nilai ujian semester I (raport) yang diperoleh dari guru wali kelas, nilai tersebut disimbolkan dalam bentuk angka.

\section{HASIL PENELITIAN DAN PEMBAHASAN}

\subsection{Hasil Penelitian.}

\subsubsection{Ketertiban Siswa di dalam Kelas.}

Cara untuk mengetahui ketertiban belajar siswa didalam kelas ialah diukur menggunakan indikator, dengan jumlah pertanyaan yang disampaikan sebanyak 31 butir. Dari hasil penyebaran angket tersebut, setelah dilakukan pentabulasian dan penganalisisan maka peneliti mengetahui bahwa ketertiban belajar siswa kelas tinggi SD Negeri No 20/1 Jembatan Mas adalah baik dengan total rata-rata jawaban angket tersebut adalah 3,60.

\subsubsection{Hasil Belajar Siswa pada Mata PelajaranPKNKelas Tinggi Sekolah Dasar Negeri No} 20/1 Jembatan Mas.

Hasil belajar yang digunakan dalam penelitian ini adalah nilai ujian semester murni yang telah didokumentasikan oleh guru wali kelas. Hasil belajar tersebut dikelompokkan berdasarkan ketegori yang telah ditetapkan sebelumnya, yaitu dalam kelompok sangat tinggi, tinggi, sedang, dan rendah.

Perhitungan ini memerlukan nilai mean dan standar deviasi untuk data kelompok yaitu sebagai berikut:

$$
\overline{\mathbf{X}}=\frac{\Sigma \mathrm{FiXi}}{\Sigma \mathrm{Fi}} \quad \text { SD }=\sqrt{\frac{\Sigma \mathrm{Fi}(\mathrm{Xi}-\overline{\mathrm{x}})^{2}}{n-1}}
$$

Langkah-langkahnya sebagai berikut:

1) Membuat Tabel Distribusi Nilai Hasil Belajar Mata Pelajaran PKN Siswa Kelas Tinggi SD Negeri No 20/1 Jembatan Mas.

$$
\begin{array}{cccc}
\mathrm{K}=1+3.3 \log \mathrm{N} & \mathrm{R} \quad=\mathrm{Xt}-\mathrm{Xr} & \mathrm{I} & =\mathrm{R} / \mathrm{K} \\
=1+3.3 \log 60 & =81-65=16 / 6 & \\
& =1+3.3(1.77) & =16 & =2,66 \\
& =1+5,841 & & \\
=6,841 & &
\end{array}
$$

Tabel1: Distribusi Nilai Hasil Belajar Mata Pelajaran PKN Siswa Kelas Tinggi SD Negeri No 20/1 Jembatan Mas

\begin{tabular}{|c|c|c|c|c|c|c|c|}
\hline $\begin{array}{c}\mathrm{N} \\
\mathrm{o}\end{array}$ & $\begin{array}{c}\text { Keterti } \\
\text { ban } \\
\text { belajar }\end{array}$ & $\mathrm{Fi}$ & $\begin{array}{c}\mathrm{X} \\
\mathrm{i}\end{array}$ & $\begin{array}{c}\mathrm{Fi} \\
\mathrm{Xi}\end{array}$ & $\begin{array}{c}\mathrm{Xi}- \\
\overline{\mathrm{x}}\end{array}$ & $\begin{array}{c}(\mathrm{Xi}- \\
\overline{\mathrm{x}})^{2}\end{array}$ & $\begin{array}{c}\mathrm{Fi} \\
(\mathrm{Xi}- \\
\overline{\mathrm{x}})^{2}\end{array}$ \\
\hline 1 & $65-67$ & 2 & 6 & 13 & - & 55,5 & 111 \\
0 & \\
& & & 6 & 2 & $\begin{array}{c}7,4 \\
5\end{array}$ & & \\
\hline 2 & $68-70$ & 1 & 6 & 11 & - & 19,8 & 316, \\
& & 6 & 9 & 04 & $\begin{array}{c}4,4 \\
0\end{array}$ & 8 \\
\hline 3 & $71-73$ & 1 & 7 & 72 & - & 2,10 & 21 \\
\hline
\end{tabular}




\begin{tabular}{|c|c|c|c|c|c|c|c|}
\hline & & 0 & 2 & 0 & $\begin{array}{c}1,4 \\
5\end{array}$ & & \\
\hline 4 & $74-76$ & 1 & 7 & 13 & 1,5 & 2,40 & 43,2 \\
& & 8 & 5 & 50 & 5 & & \\
\hline 5 & $77-79$ & 1 & 7 & 85 & 4,5 & 20,7 & 227, \\
& & 1 & 8 & 8 & 5 & 0 & 7 \\
\hline 6 & $80-82$ & 3 & 8 & 24 & 7,5 & 57,0 & 171 \\
& & & 1 & 3 & 5 & 0 & \\
\hline \multicolumn{2}{|c|}{$\Sigma$} & 6 & & 44 & & & 890, \\
& & 0 & & 07 & & & 7 \\
\hline
\end{tabular}

2) Mencari Mean Dari Sebaran Skor.

$$
\begin{aligned}
\overline{\mathrm{X}} & =\frac{\sum \mathrm{Fi} \cdot \mathrm{Xi}}{\sum \mathrm{Fi}} \\
& =\frac{4407}{60} \\
& =73,45
\end{aligned}
$$

Berdasarkan perhitungan diatas diketahui bahwa rata-rata nilai memusat pada nilai 73,45 atau 73. Selanjutnya penyebaran nilai hasil belajar siswa dengan menggunakan rumus deviasi.

3) Mencari Standar Deviasi.

$$
\begin{aligned}
\mathrm{SD} & =\sqrt{\frac{\sum \mathrm{Fi}(\mathrm{Xi}-\overline{\mathrm{x}})^{2}}{n-1}} \\
& =\sqrt{\frac{890.7}{60-1}} \\
& =\sqrt{\frac{890,7}{59}} \\
& =\sqrt{15,09} \\
& =3,88
\end{aligned}
$$

\begin{tabular}{|c|c|c|c|}
\hline $\mathrm{No}$ & Interval & $\mathrm{F}$ & Kelompok \\
\hline 1 & 77,33 ke atas & $\begin{array}{c}14 \\
\text { siswa }\end{array}$ & $\begin{array}{l}\text { Sangat } \\
\text { Tinggi }\end{array}$ \\
\hline 2 & $70,07-77,33$ & $\begin{array}{c}38 \\
\text { siswa }\end{array}$ & Tinggi \\
\hline 3 & $\begin{array}{c}70,07 \mathrm{ke} \\
\text { bawah }\end{array}$ & $\begin{array}{c}8 \\
\text { siswa }\end{array}$ & Sedang \\
\hline 4 & 60,00 & 0 & Rendah \\
\hline \multicolumn{2}{|r|}{$\Sigma$} & $\begin{array}{c}60 \\
\text { siswa }\end{array}$ & \\
\hline
\end{tabular}

4) Penentuan kategori penyebaran hasi belajar PKN, dalam hal ini pengkategorinya dilakukan tingkat sangat tinggi, tinggi, sedang, dan rendah.

Tabel 2: Tingkat Hasil Belajar

Berdasarkan tabel 2 tersebut, menunjukkan bahwa hasil belajar siswa kelas tinggi SD Negeri No 20/1 Jembatan Mas dapat digolongkan menjadi hasil belajar kategori sangat tinggi mempunyai nilai 77,33 ke atas yaitu sebanyak 14 siswa, hasil belajar tingkat tinggi 
mempunyai nilai 70,07 sampai 77,33 yaitu sebanyak 38 siswa, dan hasil belajar kategori sedang mempunyai nilai 70,07 ke bawah yaitu sebanyak 8 siswa, untuk hasil belajar kategori rendah yaitu tidak ada. Dengan demikian dapat dinyatakan bahwa dari 60 siswa kelas tinggi SD Negeri No. 20/1 Jembatan Mas memiliki kategori hasil belajar umumnya tinggi, yang mempunyai nilai 70,07 sampai 77,33 yaitu sebanyak 38 siswa.

3.2.3. Hubungan Ketertiban Belajar Siswa didalam Kelas dengan Hasil Belajar Siswa Kelas Tinggi SD Negeri No. 20/1 Jembatan Mas.

Untuk mengetahui adanya hubungan ketertiban belajar siswa didalam kelas dengan hasil belajar PKN, maka dilakukan perhitungan distribusi frekuensi. Skor angket ketertiban belajar siswa didalam kelas, dan hasil belajar siswa disatukan. Kemudian angka-angka tersebut diolah dengan rumus product moment. Untuk mengetahui adanya hubungan ketertiban belajar siswa didalam kelas dengan hasil belajar siswa sebagai berikut ini :

$$
\begin{aligned}
& \mathrm{N} \quad=60 \\
& \Sigma X \quad=6713 \\
& \Sigma \mathrm{Y} \quad=4409 \\
& \Sigma \mathrm{X}^{2} \quad=757574 \\
& \Sigma \mathrm{Y}^{2} \quad=325512 \\
& \Sigma \mathrm{XY} \quad=494861 \\
& \mathrm{r}_{\mathrm{xy}}=\frac{\mathrm{N}(\Sigma \mathrm{XY})-(\Sigma \mathrm{X})(\Sigma \mathrm{Y})}{\sqrt{\left(N \Sigma \mathrm{X}^{2}-(\Sigma \mathrm{X})^{2}\right)\left(N \Sigma \mathrm{Y}^{2}-(\Sigma \mathrm{Y})^{2}\right)}} \\
& =\frac{60 \cdot(494.861 .)-(6713)(4409)}{\sqrt{60.757 .574-(6713)^{2}}\left(60.325 .512-(4409)^{2}\right)} \\
& =\frac{29.691 .660-29.597 .617}{\sqrt{(45.454 .440-45.064 .369)}(19.530 .720-19.439 .281)} \\
& =\frac{94043}{\sqrt{(390.071)(91.439)}} \\
& =\frac{94043}{\sqrt{35.667 .702 .169}} \\
& =\frac{94043}{188.858,94} \\
& =0,498
\end{aligned}
$$

Untuk mengetahui ilai signifikan $\mathrm{r}$ dimasukan ruus tingkat signifikan dengan rumus Uji t dengan signifikan 0,05 sebagai berikut.

$$
\begin{aligned}
& \text { Diketahui } \begin{array}{c}
\mathrm{t}_{\text {hitung }}= \\
\mathrm{r} \quad=0,498 \\
\mathrm{n} \quad=60
\end{array} \\
& \mathrm{t}_{\text {hitung }}=\frac{\mathrm{r} \sqrt{\mathrm{n}-2}}{\sqrt{1}-\mathrm{r}^{2}} \\
& \mathrm{t}_{\text {hitung }}=\frac{0,498 \sqrt{60-2}}{\sqrt{1}-(0,498)^{2}}=\frac{0,498 \sqrt{58}}{\sqrt{1}-0,2480}=\frac{0,498 \cdot 7,615}{\sqrt{0,752}} \\
& \mathrm{t}_{\text {hitung }}=\frac{3,79227}{0,867}=4,374 \\
& \begin{array}{l}
\alpha=0,05 \mathrm{dF}=60-2=58 \text { adalah } 2,000 . \\
\text { Jadi } \quad \mathrm{t}_{\text {hitung }} \geq \mathrm{t}_{\text {tabel }} \quad(4,374 \geq 2,000) \text { maka signifikan. }
\end{array}
\end{aligned}
$$




\subsection{Pembahasan.}

Berdasarkan hasil penelitian diketahui bahwa ketertiban belajar siswa didalam kelas (1) indikator ketertiban belajar siswa dalam menentukan dan menggunakan cara atau strategi belajar, responden memberikan jawaban baik dengan skor 3,76. (2) Indikator ketertiban terhadap pemanfaatan waktu, responden memberikan jawaban baik dengan skor 3,55. (3) indikator tertib terhadap tugas responden memberikan jawaban baik dengan skor 3,49.

Berdasarkan analisis diketahui bahwa ketertiban belajar siswa didalam kelas tinggi SD Negeri No. 20/1 Jembatan Mas yaitu baik, dengan adanya dukungan dari ruangan yang bagus dan guru-guru yang memotivasi siswa untuk tertib belajar didalam kelas. Dilihat dari rangkuman hasil skor rata-rata ketertiban belajar siswa didalam kelas pada mata pelajaran PKN diperoleh skor rata-rata sebesar 3,60. Ini membuktikan bahwa ketertiban belajar siswa didalam kelas pada mata pelajaran PKN adalah baik. Hal ini sesuai dengan pendapat Slameto $(2003 ; 82)$ bahwa tujuan dari belajar adalah untuk memperoleh serangkaian pengetahuan,sikap, kecakapan, dan keterampilan, cara-cara yang digunakan tersebut akan menjadi ketertiban belajar siswa juga akan mempengaruhi belajar itu sendiri.

Hasil belajar siswa kelas tinggi SD Negeri No. 20/1 Jembatan Mas digolongkan sedang, yakni mempunyai nilai 70,07 sampai 77,33. Untuk itu perlu dilakukan upaya-upaya yang bisa meningkatkan hasil belajar siswa pada bidang studiPendidikan Kewarganegaraan (PKn) dan pada mata pelajaran lainnya. Diantaranya dengan meningkatkan ketertiban belajar siswa didalam kelas.

Selanjutnya rumusan masalah dalam penelitian ini yaitu (1) bagaimanakah gambaran kualiatas ketertiban belajar siswa. (2) bagaimanakah kualitas hasil belajar pada PKN. (3) apakah hubungan ketertiban belajar siswa didalam kelas dengan hasil belajar pada mata pelajaran PKN kelas tinggi SD Negeri No. 20/1 Jembatan Mas. Dari hasil penelitian diketahui bahwa hubungan ketertiban belajar siswa didalam kelas dengan hasil belajar siswa menghadirkan koefisien korelasi sebesar $=0,498$ dengan kategori tinggi. Nilai hitung 0,498 pada $\mathrm{N}=60$ dan $\alpha=5 \%$ diperoleh $\mathrm{r}_{\text {tabel }}=0,254$ dalam hal ini $\mathrm{r}_{\text {hitung }}>\mathrm{r}_{\text {tabel }},(0,498>$ $0,254)$ kemudian dikonsultasikan diinterprestasi pada tabel $r$ menunjukkan koefisien korelasi yang tinggi. Selanjutnya untuk mengetahui signifikan koefisien korelasi digunakan rumus uji $t$, diperoleh $t_{\text {hitung }}>t_{\text {tabel }}(4,374>2,000)$. Hal ini berarti terdapat hubungan yang signifikan pada mata pelajaran PKN siswa kelas tinggi SD Negeri No. 20/1 Jembatan Mas.

Hasil penelitian ini sejalan dengan penelitian yang dilakukan oleh Ariefiani (2013) yang membuktikan kedisiplinan atau ketertiban belajar memiliki hubungan dengan hasil belajar siswa pada mata pelajaran pengolahan makanan Indonesia 1 di SMK Negeri 9 Padang.

Hasil penelitian ini juga sesuai dengan penelitian Rahartiwi (2016) yang juga membuktikan bahwa kedisiplinan memiliki hubungan dengan dengan hasil belajar siswa kelas V SD Gugus Srikandi Semarang Barat. Penelitian Rahartiwi ini menunjukkan bahwa besarnya kontribusi atau peranan variabel kedisiplinan dalam menentukan keberhasilan belajar yaitu sebesar 24,32\%, sedangkan sisanya yaitu berasal dari faktor lain diluar dari variable kedisiplinan. Kontribusi variable kedisiplinan hasil belajar masing-masing mata pelajaran yaitu $7 \%$ dalam menentukan keberhasilan mata pelajaran B.Indonesia, 9,5\%, dalam menentukan keberhasilan mata pelajaran PKn, 24,5\% dalam menentukan keberhasilan mata pelajaran Matematika, 37,4\% dalam menentukan keberhasilan mata pelajaran IPA, dan 43,2\% dalam menentukan keberhasilan mata pelajaranI PS. Dengan demikian kontribusi paling tinggi kedisiplinan terdapat pada hasil belajar IPS yaitu sebesar 43,2\%.

Hasil penelitian ini juga sesuai dengan penelitian yang dilakukan oleh Apriani (2017) yang menunjukkan bahwa terdapat hubungan yang positif dan signifikan antara kedisiplinan dengan hasil belajar dengan rhitung sebesar 0,444> rtabel yaitu sebesar 0,388 . 
Hasil penelitian ini bersesuaian pula dengan penelitian Khafid dan Saroso (2007) yang menjelaskan ketertiban atau disiplin belajar dan lingkungan keluarga memiliki pengaruh terhadap hasil belajar ekonomi. Ketertiban atau disiplin secara parsial memiliki pengaruh terhadaphasil belajar ekonomi siswa kelas 8 SMPN 1 Jatinegara Kabupaten Tegal Tahun Pelajaran 2006/2007, disiplin belajar memiliki pengaruh sebesar 8,17\%, secara parsial lingkungan keluarga juga memiliki pengaruh terhadap hasil belajar ekonomi siswa sebesar $8,76 \%$. Selanjutnya secara bersama-sama atau simultan disiplin belajar dan lingkungan keluarga memiliki pengaruh terhadap hasil belajar ekonomi siswa sebesar 14,8\%, selebihnya sebesar 85,2\% faktor-faktor lain ikut memberikan pengaruh kepada hasil belajar yang tidak dikaji dalam penelitian ini, seperti faktor intelligensia, semangat belajar, strategi pembelajaran, budaya belajar, serta berbagai lingkungan seperti sekolah dan masyarakat.

Hasil penelitian ini juga sesuai dengan penelitian Rachmawati\& Noe (2014) yang mengatakan bahwa disiplin belajar memiliki hubungan dengan hasil belajar siswa pada mata pelajaran PKN di Sekolah Dasar Negeri Sumber Jaya 04 Tambun Selatan Kabupaten Bekasi. Dimana Koefisien determinasi sebesar $68 \%$ menunjukkan bahwa disiplin belajar memberikan kontribusi terhadap hasil belajar siswa. Sedangkan $32 \%$ dipengaruhi oleh factor lain yang tidak diteliti dalam penelitian ini.

\section{KESIMPULAN DAN SARAN}

\subsection{Kesimpulan.}

Berdasarkan hasil penelitian dan analisis datayang diperoleh diketahui bahwa ketertiban belajar siswa didalam kelas adalah baik dengan skor rata-rata 3,60, dan diketahui bahwa hasil belajar siswa kelas tinggi SD Negeri No. 20/1 Jembatan Mas pada mata pelajaran PKn digolongkan pada kategori sedang. Kemudian terdapat hubungan yang positif dan signifikan antara ketertiban belajar siswa didalam kelas dengan hasil belajar siswa kelas tinggi SD Negeri No. 20/1 Jembatan Mas dengan $r_{\text {hitung }} \geq r_{\text {tabel }},(0,498 \geq 0,245)$ pada taraf signifikan $\alpha=5 \%$. Dengan demikian $\mathrm{H}$ nol $\left(\mathrm{H}_{\mathrm{O}}\right)$ yang diuji ditolak, sehingga $\mathrm{H}$ alternatif $\left(\mathrm{H}_{\mathrm{a}}\right)$ diterima. Berdasarkan analisis diatas bahwa hubungan ketertiban belajar siswa didalam kelas dengan hasil belajar siswa kelas tinggi SD Negeri No. 20/1 Jembatan Mas yaitu baik.

\subsection{Saran.}

Akhirnya penulis menyampaikan serangkaian saran seperti berikut:

1. Hendaknya para orang tua berupaya meningkatkan rasa tanggung jawab mereka terhadap perihal pendidikan anak-anak mereka, terutama dalam hal ketertiban belajar anak dan memberikan perhatian yang lebih dalam pemenuhan kebutuhan belajar anak.

2. Guru sebagai orang yang paling dekat dengan anak-anak didiknya, disarankan agar lebih berusaha untuk meningkatkan ketertiban belajar siswa didalam kelas dengan cara pengarahan belajar dan bimbingan guru yang baik kepada siswa, memberi bantuan kepada siswa dalam belajar, sehingga mampu meningkatkan hasil belajar siswa.

3. Kepada guru wali kelas hendaknya membangkitkan dan mendorong siswa agar lebih tertib dalam belajar didalam kelas.

4. Kepada siswa hendaknya mempertahankan ketertiban belajar siswa didalam kelas memiliki pengaruh yang positif terhadap hasil belajar. 


\subsection{Ucapan Terima Kasih.}

Ungkapan rasa hormat yang tinggi dan ucapan terimakasih yang mendalam penulis sampaikan kepada kepala sekolah Sekolah Dasar Negeri No. 20/1 Jembatan Mas yang sudah memberikan respon yang baik dan memberikan izin guna melaksanakan penelitian, begitu juga kepada semua responden terhormat yang telah berpartisifasi aktif demi kelancaran penelitian ini, dan kepada pimpinan dan jajaran peneglola Jurnal Sosio Humaniora Lembaga Penelitian dan Pengabdian kepada Masyrakat (LPPM) Universitas Jambi yang telah berkenan menerima dan menerbitkan artikel penulis ini.

\section{DAFTAR PUSTAKA}

Afifah. 2011. Hakikat Pembelajaran PKN. (Online),(http://afifahmend.blogspot.com//2011/03.html).

Apriani, Rosalia. 2017. Hubungan Kedisplinan dengan Hasil Belajar pada Tema 9 Subtema 1 Siswa Kelas IV SD Negeri 5 Jatimulyo Lampung Selatan. Skripsi. Fakultas Keguruan dan Ilmu Pendidikan Universitas Lampung Bandar Lampung.

Ariefiani, Mega Nita. 2013. Hubungan Disiplin dengan Hasil Belajar Siswa pada Mata Pelajaran Pengolahan Makanan Indonesia 1 di SMK Negeri 9 Padang, Skripsi. Program Studi Pendidikan Kesejahteraan Keluarga Fakultas Teknik Universitas Negeri Padang.

Arikunto, S. 2009. Dasar-Dasar Evaluasi Pendidikan. Jakarta. PT Bumi Aksara .2012. Statistika Untuk Penelitian. Bandung. Alfabeta

Jupriyanto. 2012. Hubungan Kedisiplinan Dalam Mengerjakan Pekerjaan RumahDengan Hasil Belajar Siswa Kelas Tinggi SDN 70/1 Simpang Terusan. Jambi: Universitas jambitidak diterbitkan. Justitia. $2012 . \quad$ Ketertiban belajar. (Online). http://justitia1.wordpress.com

Khafid, Muhammad dan Saroso. 2007. Pengaruh Disiplin Belajar dan Lingkungan Keluarga Terhadap Hasil Belajar Ekonomi. Jurnal Pendidikan Ekonomi Vol. 2 No. 2 Juli, Tahun 2007. Hal. 185-204.

Muspawi, Mohamad. 2017. Penggunaan Metode Mengajar Oleh Guru PAI pada SDN No.142/VII Pulau Aro Kecamatan Pelawan Kabupaten Sarolangun. Jurnal Sains Sosio Humaniora Volume 1 Nomor 2 Tahun 2017.Hal. 174-185.

Rachmawati, Nisa Dian\& Noe, Wahyudin. 2014. Hubungan Disiplin Belajar Dengan Hasil Belajar Siswa pada MataPelajaran PKN di Sekolah Dasar Negeri Sumber Jaya 04 Tambun Selatan Kabupaten Bekasi. Jurnal Pedagogik Vol. II, No. 2, September 2014. Hal. 20-25.

Rahartiwi, Meitri. 2016. Hubungan Antara Kedisiplinan Dengan Hasil Belajar Siswa Kelas V SD Gugus Srikandi Semarang Barat. Skripsi. Jurusan Pendidikan Guru Sekolah Dasar Fakultas Ilmu Pendidikan Universitas Negeri Semarang.

Sugiyono. 2011. Metode Penelitian Pendidikan. Bandung: Alfabeta

Sugiyono. 2010. Penelitian Kuantitatif. Bandung: Alfabeta.

Suryosubroto. 2010. Manajemen Pendidikan Di Sekolah. Jakarta. Rieneka Cipta

Sobry Sutikno. 2013. Belajar dan Pembelajaran: Upaya Kreatif dalam Mewujudkan Pembelajaran yang Berhasil, Lombok: Holistica.

Undang-Undang RI. 2003. Undang-Undang Republik Indonesia Nomor 20 Tahun 2003 tentang Sistem Pendidikan Nasional.

Winataputra,Udin S, 1986. Belajar Dan Pembelajaran: Universitas Terbuka.

Yunimel. 2012. Hubungan Motivasi Dengan Hasil Belajar Siswa Kelas TinggiSDN 55/1 Sridadi. Jambi: Sikripsi. Universitas Jambi 